Magda Nabiałek

Wydział Polonistyki

Uniwersytet Warszawski

\title{
DRAMATYCZNA NARRACJA - MIĘDZY BETLEJEM POLSKIM LUCJANA RYDLA A BIWAKIEM POD GOLYM NIEBEM MARIANA PANKOWSKIEGO
}

Dramat jako swoista dysputa epistemologiczna, struktura słowna warunkująca zaistnienie aktu percepcji innego doświadczenia wizualnego sytuuje się w pobliżu zagadnień, które fundują problematykę odbioru przekazu biblijnego. Filiacja świętej opowieści i utworu scenicznego dotykać może fundamentalnego problemu, jakim jest istota przekazu biblijnego. Wyjątkowość tej narracji zasadza się w pewnym sensie na relacji między widzialnym i niewidzialnym, na poszukiwaniu ukrytego ujawniającego się w miejscach styku obrazu i słowa. W tym sensie sama tematyka opowieści biblijnych i sposób ich prezentacji uruchamiają problemy zasadnicze dla samej struktury gatunku dramatu.

Od dramatów religijnych, misteriów, tekstów, które nawiązują do problematyki biblijnej oczekujemy szczególnego rodzaju prezentacji świata przedstawionego. Filiacja łącząca te utwory z narracją biblijną zdaje się bowiem wymuszać na autorze szczególny rodzaj operowania słowem dramatycznym, niecodzienny sposób konstrukcji mikrokosmosu scenicznego i połączenie go z makrokosmosem za pomocą precyzyjnie określonych reguł. Dramaty, które w jakikolwiek sposób nawiązują do Starotestamentowych czy też Nowotestamentowych opowieści nawet w tak nieoczywisty sposób, jak czyni to Samuel Zborowski Juliusza Słowackiego - zdają się operować wyjątkowym typem słowa, dzięki któremu prezentuje nową „wiarę widzącą" . Konstatacja ta prowadzi badacza w kierunku

${ }^{1}$ „W Samuelu Zborowskim Słowacki - dając wyraz dążenia do stania się niejako »całością« - operuje jednocześnie szczególnym słowem, Słowem-Logosem, które znosi granicę między językiem i światem, nadaje im, na wzór Boskiego fiat-jedność. Genezyjska rzeczywistość w dramacie jest słowem - poprzez nie bowiem zostaje ona odsłaniana przez Eoliona, Lucyfera, samego poetę-autora, który się w nim manifestuje, jest reprezentowany, przedstawiony w końcu. A jednocześnie słowo genezyjskie - w ustach tych wszystkich postaci, włącznie z trojako obecnym autorem - staje się rzeczywistością: faktyczną bądź potencjalną” (J. Skuczyński, „Moc przeze mnie gada” Autor i jego strategie nadawczoodbiorcze, w: Świat z tajemnic wyspowiadany... Studia o „, Samuelu Zborowskim” Juliusza Słowackiego, pod red. M. Kalinowskiej, J. Skuczyńskiego i M. Bizior, Toruń 2006, s. 90). 
rozważań poświęconych pozycji odbiorcy, która miałaby zostać zapisana w strukturze dzieła. To właśnie sugerowana przez kompozycję tekstu perspektywa oglądu świata przez widza bądź czytelnika utworu, zdaje się tym obszarem, w ramach którego dramat religijny czy biblijny ujawniają swój szczególny status w stosunku do innych utworów scenicznych.

W prezentowanym artykule, który stanowi raczej rodzaj zapowiedzi badań aktualnie przeze mnie prowadzonych, aniżeli formę ich zwieńczenia. Chciałabym zająć się próbą zarysowania szczególnej specyfiki dramatów o konotacjach biblijnych, ich poetyki ujawniającej się jednak nie tyle w warstwie tematycznej dzieła, ile jej płaszczyźnie kompozycyjnej, ze szczególnym uwzględnieniem projektowanej pozycji odbiorczej. Materiałem dla owych badań staną się dwa utwory nawiązujące do jednej z najważniejszych narracji biblijnych czyli tej poświęconej wydarzeniom, które rozegrały się w Betlejem.

Zaprezentowana poniżej analiza Betlejem polskiego Lucjana Rydla oraz Biwaku pod gołym niebem Mariana Pankowskiego wyrasta z przekonania, że narzędziem, które posłużyło do kierowania spojrzenia odbiorcy w stronę biblijnego oglądu świata, nie stała się jedynie tematyczna zawartość tekstu, ale również jego forma dramatyczna. Dramat jako gatunek transgresyjny ${ }^{2}$ sytuujący się między literaturą a teatrem, stanowi pole nieustannych filiacji między słowem a obrazem, a co za tym idzie: stawia pytanie o wielopoziomową relację łączącą czytanie/pisanie i widzenie/postrzeganie rzeczywistości. Pytanie, które dla narracji biblijnej również okazuje się kluczowe. Wykorzystanie do analiz wymienionych wyżej utworów semiotyczno ${ }^{3}$-hermeneutycznych ${ }^{4}$ narzędzi ${ }^{5}$, którymi posługiwano się z powodzeniem przy interpretacji ikon pozwala zaś na nowe postawienie problemu konstrukcji oraz kompozycji tych dzieł.

W perspektywie prowadzonych przeze mnie badań struktura dramatyczna jawi się jako wynik ciągłych starć między patrzeniem i mówieniem, obrazem a słowem, spojrzeniem a materią poetycką, w której zostaje zamknięte doświad-

${ }^{2}$ Pojęciem tym posługuję się za Ireną Górską. Por. I. Górska, Dramat jako filozofia dramatu na przykładzie twórczości Tadeusza Różewicza, Poznań 2004, s. 15.

${ }^{3}$ Czołowym przedstawicielem tego nurtu badań jest Boris Uspieński. Por. B. Uspieński, O systemie przekazu obrazu $w$ rosyjskim malarstwie ikon, w: Semiotyka kultury, wybór i oprac. E. Janus i M. R. Mayenowa, Warszawa 1977; tegoż, The Semiotics of the Russian Icon, Lisse 1976.

${ }^{4}$ Por. P. Evdokimov, Sztuka ikony. Teologia piękna, przeł. M. Żurowska, Warszawa 1999, P. Florenski, Ikonostas i inne szkice, przeł. Z. Podgórzec, Warszawa 1981; M. Quernot, Ikona. Okno ku wieczności, przeł. H. Paprocki, Białystok 1997. Warto również przywołać powstałą całkiem niedawno polską pracę poświęconą tej tematyce: K. Klauz, Teologiczna hermeneutyka ikony, Lublin 2000.

${ }^{5} \mathrm{Na}$ celowość łączenia tych dwóch perspektyw badawczych wskazuje B. DąbKalinowska, Ikony i obrazy, Warszawa 2000. 
czenie podmiotu. Okazuje się, że kluczowym miejscem dramatu jest nie tyle moment jednoznacznego wydzielenia sfery prezentacji i opowieści, ile punkt ich styku, wzajemnego zapętlenia się słowa i obrazu, a także - w przypadku niektórych dzieł, jak te poniżej omawiane - jego wydobycie na powierzchnię tekstu. Jeśli zaś przyjąć, że dramat to akt trwałej hipostazy, to tradycyjne dla tego gatunku opozycje, takie jak podział na mimesis i diegesis okazują się niemożliwe do utrzymania. To właśnie analiza dramatów biblijnych pozwala dostrzec, jak istotne dla kompozycji tych utworów nie jest rozdzielenie tych dwóch warstw, a właśnie ich zapętlenie. Na przykładzie tych utworów dostrzec można bowiem wyraźnie, że to struktura słowna, w której zapisane zostaje doświadczenie wizualne, warunkuje zaistnienie aktu percepcji dzieła. Źródłem dramatu jest spojrzenie, którym obdarzony zostaje świat przedstawiony. Patrzenie nie może jednak zrealizować się tutaj inaczej niż dzięki określonej perspektywie zakładającej zapośredniczenie widzenia przez konwencję słowną. Język to jednocześnie warunek zaistnienia obrazu oraz zasłona oddzielająca spojrzenie od świata.

Warto zauważyć, że historia biblijna, do której nawiązują obydwa dramaty sytuuje je w pobliżu sztuki i teologii ikony rozumianej jako ,swego rodzaju okno prowadzące ku światu duchowemu"6. Jednym z podstawowych celów ikony jest z kolei „przezwyciężenie rozdarcia między światem materialnym a noetycznym, które dokonuje się poprzez oczyszczenie (...) z tego wszystkiego, co ma związek z rzeczywistością materialną"7 . Jest ono możliwe, aczkolwiek jedynie w momencie uświadomienia sobie ograniczeń, jakim ulega ludzki sposób widzenia świata ${ }^{8}$. Wiedza ta przychodzi zaś w momencie nałożenia się widzialnego i niewidzialnego, a w przypadku tekstu dramatycznego - słowa i obrazu. Czytanie dramatu prowadzi do zetknięcia z wielowymiarowością utworu, aktem nieustannej hipostazy rodzącym się na styku obrazu i słowa. Proces rozumienia wymaga zaś próby opisu tego zjawiska.

Z pełną świadomością przedmiotem moich obserwacji czynię dwa teksty, które sytuować należy w obrębie gatunku jasełek. Jasełka swym początkiem sięgają XIII wieku. Wywodzą się z franciszkańskiego zwyczaju ustawiania w kościołach nieruchomych figur stanowiących podstawowy element prezentacji scen z szopy betlejemskiej ${ }^{9}$. Literacko-teatralna forma powstała na podstawie

${ }^{6}$ I. Jazykowa, Świat ikony, przeł. H. Paprocki, Warszawa 1998, s. 22.

${ }^{7}$ B. Dąb-Kalinowska, dz. cyt., s. 56.

${ }^{8}$ „Wnętrze ducha jasne - wszyscy, którzy wyjdą z ducha, są w ciemności zewnętrznej” (J. Słowacki, Glosy na marginesie egzemplarza „Biblii”, w: tegoż, Dzieła, red. J. Krzyżanowski, t. 11, Warszawa 1959, s. 312).

${ }^{9}$ Zob. Stownik folkloru polskiego, red. J. Krzyżanowski, Warszawa 1965, s. 149-151. J. Dürr-Durski, Jak powstała polska szopka betlejemska?, w: Literatura, komparatystyka, folklor. Księga poświęcona Julianowi Krzyżanowskiemu, pod red. M. Bokszczanin, S. Frybesa, E. Jankowskiego, Warszawa 1968. 
tego zwyczaju charakteryzuje się schematycznością akcji scenicznej, jasnym zakreśleniem przestrzeni scenicznej, precyzyjnie wyznaczonym ruchem scenicznym, a co szczególnie ważne w kontekście prowadzonych rozważań - marionetkowością postaci pojawiających się na scenie. Co ciekawe, to wszystko przy niejednokrotnie czytelnie wydobytej na powierzchnię tekstu lub przedstawienia widowiskowości utworu. O ile, jak słusznie zauważają badacze, sama scena pokłonienia się dzieciątku w żłobie, nie stanowi gatunkowego wyznacznika jasełek, o tyle kolejno pojawiające się na scenie postaci zawsze w czytelny sposób nawiązują do owego fundamentalnego dla tej historii momentu. Podejrzewać by więc można, że jasełka nawiązują do wielkiej biblijnej narracji, jednakowoż ich dramatyczność kryje się przede wszystkim w widowiskowej warstwie dzieła. W moim przekonaniu, to tylko jeden z możliwych wymiarów dramatyczności tych tekstów. Ta, która funduje cały gatunek, kryje się zaś na linii przecięcia się słowa i obrazu.

Maria Renata Mayenowa, analizując Wesele Stanisława Wyspiańskiego w kontekście jasełkowości tego dramatu, wskazała na wiele istotnych cech gatunku. Z jedną tezą badaczki trudno się jednak zgodzić. W rozdziale poświęconym przestrzeni konstatuje ona, że w Weselu czytelnik ma do czynienia z przestrzenią ściśle ograniczoną, zamkniętą, niezmienną i realistyczną. Odbiorca zostaje jednak skonfrontowany ze sceną zawieszoną $\mathrm{w}$ istniejącej przestrzeni, ale nieokreślonej szczegółowo i o niewielkim zasięgu. Jej główną cechą jest nie tylko realistyczno-malarski aspekt, lecz także integracja różnych stanów społecznych, dzięki czemu skupia ona i kondensuje dramatyczne napięcie. Mayenowa konkluduje, że „można by się tutaj dopatrywać pewnych, dalekich pokrewieństw ze sceną szopki, która też skupiała ze sobą wszelkie stany i zawody". Owe nawiązania są natomiast „bardzo dalekie, trudno bowiem mówić o symbolizmie przestrzeni w szopce. Przestrzeń szopki to pusta fizyczna przestrzeń dziania się, jej symboliczność już dawno wyparowała"10. O ile można dyskutować nad tym, co dla autorki O języku poezji Jana Kochanowskiego oznacza symboliczność, o tyle zdecydowanie nie sposób zgodzić się, że miejsce sceniczne w jasełkach to pusta przestrzeń dziania się, malownicze tło, które oprócz ramowania wydarzeń, nie pełni żadnej innej funkcji.

Specyfika przestrzeni jasełkowej kryje się moim zdaniem w charakterystycznym przecięciu linii scenicznego tła i perspektywy bohatera. Naturalne dla jasełek okazywałoby się więc nie tyle sytuowanie pozycji odbiorczej na zewnątrz bądź wewnątrz scenicznego mikrokosmosu, ile nieustanne przecinanie się tych dwóch optyk. Podobną propozycję, dotyczącą ogólnej konstrukcji dramatycznej sformułował kiedyś Tadeusz Kowzan. Po pierwsze, sugerowane przez niego

${ }^{10}$ R. Kapłanowa [M.R. Mayenowa], ,, Wesele” Stanisława Wyspiańskiego. Problemy kompozycji, Warszawa 2013, s. 27-28. 
rozwiązanie zakładało jednak nieustanne przechodzenie odbiorcy między jedną a drugą perspektywą oglądu. Po drugie zaś - zdaniem badacza - pełne ujawnienie się tego zjawiska możliwe okazywało się dopiero podczas realizacji teatralnej $^{11}$. Ja z kolei, wychodząc z założenia o potencjale kryjącym się w specyfice jasełek - chciałabym skupić się na próbie analizy momentów przecięcia się czy też nałożenia owych dwóch perspektyw. Ich połączenie - które można by określić mianem zerowego punktu widzenia - stanowi dla mnie narracyjny moment sztuki dramatycznej. Moment, który dla gatunków tak szczególnych jak jasełka, stanowi swoiste sine qua non. Jest to bowiem sygnał istnienia wyższego poziomu wewnątrztekstowej komunikacji dramatu. Tej, której wyraz stanowi kolęda-kołysanka. Warto przypomnieć, że jej narodziny wiązać należy z postacią św. Franciszka z Asyżu, który w 1223 r. zapoczątkował w Greccio obrzęd kołysania Dzięciątka w żłobie. W Polsce obrzęd ten został nazwany jasełkami (od miejsca nad żłobem, gdzie umieszczano paszę dla bydła) ${ }^{12}$. W tym kontekście nie dziwi stwierdzenie Krzysztofa Kurka i Wiesława Wydry, że „kuszącym projektem badawczym byłoby wskazanie źródeł (formalnych i tematycznych) pastorałek dramatycznych w obrębie pieśni i form widowiskowych związanych z adoracją żłóbka, sięgającą w Polsce drugiej połowy XIV wieku"13. Ów moment połączenia słowa $\mathrm{z}$ aktem percepcji obrazu ściśle wiąże się z samymi narodzinami gatunku, a tym samym przekłada na problematykę genologiczną i - co jeszcze chyba ważniejsze - epistemologiczną związaną z tymi utworami.

Sposób sproblematyzowania zagadnienia poznania w omawianych utworach to kolejny aspekt prowadzonej przeze mnie analizy. Jest to kwestia istotna, ponieważ w wypadku dramatu filiacja między słowem a obrazem przekłada się na jeszcze jeden aspekt konstrukcji scenicznej, jakim jest charakterystyczne przecięcie się dwóch sytuacyjno-funkcjonalnych ról: wewnętrznego reżysera oraz wewnętrznego widza ${ }^{14}$. Dla Anne Übersfeld ten moment to istota przekazu dramatycznego ${ }^{15}$, owo szczególne non-dit dzieła. Żaden inny gatunek literacki tak czytelnie nie akcentuje konfliktu, albo raczej specyficznego rodzaju filiacji,

${ }^{11}$ T. Kowzan, Teatr $w$ teatrze czyli o dialektyce iluzji scenicznej, „Dialog” 1971, nr 4.; tegoż, Znak i teatr, Warszawa 1998.

${ }^{12}$ M. Bokczyszanin, Kolęda, w: Słownik literatury staropolskiej, red. T. Michałowska, Wrocław 1998, s. 372.

${ }^{13}$ K. Kurek, W. Wydra, Między ,, sacrum” a „,profanum”... Nieznany tekst pastoratki dramatycznej z kregu kaliskiego kolegium jezuickiego, w: Ko-mediana. Prace ofiarowane Profesor Dobrochnie Ratajczakowej, pod red. E. Guderian-Czaplińskiej i K. Kurka, Poznań 2013, s. 127.

${ }^{14} \mathrm{Na}$ kluczowe znaczenie tych dwóch kompetencji dla semantycznej figury spektaklu fundującej strukturę komunikacyjną dramatu wskazywała D. Ratajczakowa, Stuga dwóch panów: dwoisty żywot dramatu, „Teksty Drugie” 1990, nr 5-6.

${ }^{15}$ A. Ubersfeld, Lire le théătre III. Le dialogue de théătre, Paris 1966, s. 104. 
między wypowiedzią a sytuacją wypowiadania. Dzięki temu dramaty nawiązujące do historii biblijnej, modyfikujące ją lub też stanowiące realizację gatunków scenicznych o wyraźnej proweniencji biblijnej, mają szansę dotknąć kluczowych dla doświadczenia człowieka problemów natury epistemologicznej.

Betlejem Polskie Lucjana Rydla (prem. 1904 we Lwowie, wyd. 1906) to jeden z najbardziej znanych przykładów polskich jasełek. Utwór prezentujący jasno określony moment historii biblijnej zamknięty w tradycyjnej młodopolskiej ludowo-narodowej ramie. Z tego też względu dość często lekceważony, niedoceniany tekst, uznany za typową realizację gatunku. Już na samym początku analiz okazuje się jednak, że wewnątrz tej stabilnej dla formy szopki struktury, Rydel dokonał istotnych przesunięć kompozycyjnych.

Zastanawiająca jest już sama zasada dzielenia przestrzeni scenicznej. Wydaje się bowiem, że odbiorca tekstu Rydla ma do czynienia z dwoma mechanizmami spacjalnymi pozwalającymi na wytworzenie szczególnego rodzaju przestrzeni dramatycznej, w której zrealizować się może historia biblijna. Po pierwsze, przestrzeń dramatu zostaje podzielona na trzy części: pastwiska, na których przebywają pasterze, dwór Heroda i kluczowe lieu, jakim jest żłobek. Zasada podziału jest utrzymana konsekwentnie przez cały utwór - każdy akt dzieje się w jednej, jasno nakreślonej przestrzeni. Warto jednak zwrócić uwagę na szczególny (wertykalny) podział przestrzeni, którego to ośrodkiem stają się dramatis personae. W każdym z aktów pojawiają się postaci działające, jednocześnie opisujące otaczającą je przestrzeń oraz postaci nadające (poprzez swoje wypowiedzi) działaniom bohaterów (oraz samej przestrzeni) ściśle religijny wymiar. Są to przede wszystkim Chóry Aniołów. To one, śpiewając pieśni bożonarodzeniowe nadają zachowaniom postaci oraz całej historii zaprezentowanej w utworze boskie piętno. Passusy wygłaszane przez chór tworzą więc swoistą ramę, za pomocą której możliwa okazuje się percepcja dramatu w perspektywie biblijnej opowieści. Ów podwójny podział przestrzeni nie wyczerpuje jednak rozwiązań zastosowanych przez Rydla. Przecięcie się zasady wertykalnej i horyzontalnej otwiera szczególne miejsce w strukturze tego dramatu. Powstały w ten sposób obszar zostaje zagospodarowany przez wybranych bohaterów. W akcie pierwszym taką postacią jest Bartos. Wygłaszane przez niego komentarze zdecydowanie wyróżniają go z całej grupy pasterzy:

\section{BARTOS}

Dyć to mili bracia samiście słyseli,

Co święci anieli do nas powiedzieli,

Ino nie wiem, cyście zrozumieli wszystko ${ }^{16}$.

${ }^{16}$ L. Rydel, Betlejem polskie, w: L. Rydel, Dramaty wybrane, pod red. L. Tatarkowskiego, Wrocław 1983, s. 301. Wszystkie wyróżnienia pochodzą od autorki artykułu. Numery stron dramatu podaję w nawiasie w tekście głównym. 
Bartos zdaje się owo „wszystko” na swój sposób nie tylko dostrzegać, lecz także rozumieć. Wskazuje na to między innymi czytelne nawiązanie (w jednej $\mathrm{z}$ jego wypowiedzi) do historii grzechu pierworodnego. Bohater natomiast nie stara się wcale przekroczyć przypisanego mu miejsca w przestrzeni, nie aspiruje do roli bohatera, który wie i rozumie więcej. Nie przeszkadza mu to jednak w uważnej percepcji i dokonaniu umiejętnego rozpoznania własnych uwarunkowań wpływających na właściwy mu sposób postrzegania świata.

\title{
BARTOS
}

Jaj świeżych pół kopy

Zaniosę do szopy

Na poleweckę (s. 304-305).

Dzięki połączeniu starannej obserwacji własnego osadzenia w przestrzeni i świadomości istnienia wyższej perspektywy oglądu zdarzeń, Bartos otwiera sobie drogę do innej percepcji historii rozgrywającej się przed nim niż ta, która przypisana zostaje pozostałym bohaterom. Ponadto, jego postać wydobywa specyficznie rozumianą terytorialnośćc ${ }^{17}$ dzieła Rydla. Mam tutaj na myśli tę związaną z tradycyjnym podziałem na platea i locus oraz odpowiadającymi im typami dystansu dzielącego odbiorcę i świat przedstawiony. Jak pokazują analizy szekspirologów, takich jak Robert Weimann, usytuowanie się danej postaci w konkretnej przestrzeni znacząco wpływa zarówno na jej pozycję wobec innych bohaterów, jak i sposób odbioru przez czytelnika lub widza ${ }^{18}$. Bartos jest właśnie taką szczególnie „pozycjonującą się” postacią.

Uznanie Bartosa za postać zyskującą wyższe widzenie świata byłoby sporym nadużyciem. Warto natomiast zauważyć, że postać ta otwiera drogę do szczególnego, bardziej świadomego poznawania świata, które stanie się udziałem kolejnych bohaterów (nie tylko Betlejem Polskiego Rydla), jak również - a może przede wszystkim - samego odbiorcy utworu:

\author{
BARTOS \\ Co kto może, to zaniesie — weźmiemy, co mamy, \\ Bo On na ochotę \\ chęć - nie na złote \\ Patrzy podarki (s. 305).
}

${ }^{17}$ S. Mullaney, Miejsce sceny. Zezwolenie, teatr $i$ wtadza w renesansowej Anglii, przeł. O. Kaczmarek, w: Teatr elżbietański, red. A. Chałupinik, Warszawa 2015.

${ }^{18}$ R. Weimann, Shakespeare i tradycja ludowa, przeł. P. Morawski, w: Teatr elżbietański, dz. cyt. 
Robert Weimann w przywoływanych powyżej analizach stwierdza, że szczególnie interesujące okazują się te dramatis personae, które usiłują albo przekroczyć granice oddzielające locus i platea, albo też nieustannie funkcjonować na ich styku. Bartos zdaje się być taką właśnie postacią, a dzięki jego wypowiedziom Betlejem polskie okazuje się utworem niepozbawionym wymiaru epistemologicznego. Kolejny etap dyskusji poświęconej poznaniu stanowi postać Arcykapłana, który tak zwraca się do Heroda:

\section{ARCYKAPŁAN \\ Trzech królów przed Nim czołem uderzy; \\ Już ze wszech stron ciągną rzesze, \\ Kędy na stajennej strzesze \\ Gwiazda goreje.}

\section{Mnie Pan zdjął z oczu wszelką zasłonę:}

Czasy twych rządów są policzone,

Za twe gwałty li uciski

Sądu Boga jesteś bliski,

Srogi mocarzu (s. 321)!

Wypowiedź Arcykapłana można traktować jak sygnał przejścia z jednej perspektywy do drugiej. To znak przekroczenia granicy między widzialnym a niewidzialnym. Warto natomiast zwrócić uwagę, że doświadczenie bohatera zamknięte zostaje w strukturze słownej. Dostrzeżenie tych wszystkich przejść: od mowy do obrazu, a potem znów do mowy, pozwala otworzyć swoiście rozumiane miejsce dla czytelnika tekstu Rydla. Tylko on (a nie żadna postać dramatu) ma bowiem szansę zauważyć owe pęknięcia w pozornie przecież spójnej i przy tym widowiskowej scenie.

Na problematyczność przekroczenia granicy między widzialnym i niewidzialnym Rydel wskazuje w Betlejem polskim co najmniej jeszcze jeden raz. Chór Matek konfrontujący się z Herodem to moment, w którym dochodzi do sygnalizacji konieczności podjęcia przez króla procesu autorefleksji, samoobserwacji własnych zachowań prowadzonej z wyższego poziomu. Jest to tylko postulat, który nie znajdzie swojej praktycznej realizacji w prezentowanej historii:

\section{MATKA}

Puśćcie mnie! Puśćcie! Do oczu mu stanę...

Krew dziecka rzucę mu w twarz!

II MATKA

Zbójco! Na dziatki patrz pomordowane,

Na rozpacz, na lament nasz!

III MATKA

Herodzie, niech cię piorun boży spali! 


\section{MATKA \\ Niech żywcem stoczy cię trąd! \\ V MATKA \\ Krew naszych dzieci waży Bóg na szali \\ I woła cię na swój sąd (s. 332)!}

Rydel zdaje się twórczo wykorzystywać tradycję jasełek. Niektóre postaci, mimo swojej marionetkowości, wygłaszają sądy, w których można upatrywać sygnału istnienia owego zerowego punktu widzenia, o którym pisałam na początku. Punktu, który pozwala na obserwację własnego widzenia - zdzierania zasłony, przekraczania granic widzenia, zmiany kierunku spojrzenia, tak bohaterów, jak i odbiorcy tekstu. W tej perspektywie autor Betlejem polskiego okazuje się - wbrew tradycyjnym rozpoznaniom - twórcą, który świadomie kształtował zastaną materię dramatyczną i wydobywał z niej fundamentalną dla narracji biblijnej problematykę epistemologiczną. Tym bardziej intrygujący w tym kontekście jest brak owych sygnałów w akcie trzecim zogniskowanym na pochodzie wokół betlejemskiego żłobka. Odpowiedzi na pytanie o owo odstępstwo szukać można u drugiego bohatera niniejszego artykułu czyli Mariana Pankowskiego.

W kontekście prowadzonych w tym artykule rozważań interesuje mnie szczególnie jedna scena utworu Pankowskiego, nawiązująca wprost do tytułu dzieła i stanowiąca klucz do jego konstrukcji. To w obrazie nocnego biwaku książąt Wschodu pod Jerozolimą, a nie w ostatnim passusie tekstu (jak zdaje się sądzić większość badaczy), kryje się źródło semantyki tego utworu.

Tekst Pankowskiego stanowi zagadkową modyfikację gatunkowego wzorca jasełek, ponieważ utwór został pozbawiony kluczowej sceny szopki ${ }^{19}$. Odbiorca Biwaku pod gołym niebem (prem. 2000 w Warszawie, wyd. 1959) zostaje skonfrontowany $\mathrm{z}$ tekstem, który prezentuje mędrców podążających do Zbawiciela. Pankowski prezentuje ich przed spotkaniem w Betlejem i po nim. Dramat został natomiast pozbawiony bezpośredniej sceny pokłonu. Autor Teatrowania nad świętym barszczem wprowadza za to do dzieła kadr zogniskowany wokół nocnej rozmowy mędrców, prowadzonej już po spotkaniu ze Świętą Rodziną. Po tej dyskusji mędrcy się rozstają, a Kasper postanawia wrócić do Betlejem.

Przywołana rozmowa jest charakterystyczna z kilku powodów. To jedna z trzech scen tego dramatu, która rozgrywa się w otwartej przestrzeni. Większość ujęć ma miejsce w domu Józefa, pałacu Heroda, na ulicach Jerozolimy. Jedynie omawiana rozmowa mędrców, ucieczka Miriam i Józefa oraz ostatnia scena dzieła rozgrywają się w tak rozległych przestrzeniach. W przypadku nocnego biwaku ów brak barier

${ }^{19}$ Por. K. Ruta-Rutkowska, O dwóch dramatach Mariana Pankowskiego, „Ogród” $1992 \mathrm{nr} \mathrm{3/4.}$ 
i granic spacjalnych jest wyraźnie zaznaczony w didaskaliach, a znaczenie tego zabiegu wzmacnia zaś jeszcze tytuł utworu. Odbiorca ma wrażenie zanurzenia dyskusji między dramatis personae w scenicznej próżni, pod „gołym niebem” właśnie.

Ową nieokreśloność, rozległość, a więc i monstrualność przestrzeni sygnalizuje także za pomocą wypowiedzi samych bohaterów. Baltazar mówi o „niezamkniętych oczach" Kaspra i zdaje się, że określenie to odnieść można do wszystkich trzech książąt. Paradoksalnie przyczyną tego stanu bohaterów nie jest „betlejemski cud”. Gdyby tak było, to jak mówi Kasper, „zostaliby wryci, oślepli". Zamiast tego oczy ich pozostają otwarte ${ }^{20}$.

Owo „otwarcie wzroku” wywołuje konfrontacja wyobrażeń z tym, co miało pozostać niewidzialne. A okazało się ,proste i prawdziwe”. Przecież „nie można przyjść do Boga, powiedzieć $>>$ dzień dobry $<<$ jego rodzicom i przyglądać im się jak zamorskim kupcom"21, a takie właśnie doświadczenie stało się udziałem Baltazara, Melchiora i Kaspra. Spotkanie ze Świętą Rodziną okazuje się dla bohaterów momentem konfrontacji własnych wyobrażeń z obrazem ukrytym w przestrzeni betlejemskiej szopy. Nie tyle nawet własnych przekonań, co narracji, która je ukierunkowała: „Noc... >>dziwna noc $<<,>>$ dziwni przybysze ze Wschodu $<<\ldots$ rok podróży, gwiazdy i proroctwa..."22.

Pankowski, dzięki usunięciu sceny pokłonu mędrców złożonego Dzieciątku otwiera przestrzeń do samoobserwacji bohaterów. Tylko usunięcie obrazu poza obszar sceny, obserwacja ,przez dziurkę od klucza” pozwala na dostrzeżenie relacji między spojrzeniem a wzrokiem patrzącego. Wydaje się, że to właśnie ten proces sanocki dramaturg stara się zainicjować $\mathrm{w}$ analizowanej przeze mnie scenie. Jedna $\mathrm{z}$ wypowiedzi Kaspra zdaje się na te autorskie zamierzenia wskazywać wprost:

\section{KASPER}

Tak, noc udziwnia i przydaje rzeczom tajemnicy, jak suknia ciału, ale my wiemy, że ciało odziane to nic innego jak tylko ciało i suknia... a skoro znamy i jedno, i drugie (s. 75)?

Zainicjowany w ten sposób proces początkowo wywołuje sprzeciw książąt. Nie chcą uznać bezsensu drogi, którą przebyli. Melchior i Baltazar proponują modyfikację czasową (,,a gdyby powrócić tu znowu... po latach”) i przestrzenną (,,ponowna nasza droga, powtórne zapukanie do drzwi tajemnicy"). Kasper nie godzi się na sugerowane rozwiązania. Zamiast tego dokonuje konfrontacji własnych wyobrażeń z doświadczonym obrazem cudu:

${ }^{20}$ Por. K. Latawiec, Scena „,bożych kukiet”, w: tejże, Na scenie świata i teatru. O dramaturgii Mariana Pankowskiego, Kraków 1994.

${ }^{21}$ M. Pankowski, Biwak pod gotym niebem, w: tegoż, Dramaty, Warszawa 2015, s. 74.

22 Tamże, s. 75. 


\section{KASPER}

(...) boli mię, że przez lata lepiłem go z zachwytów młodości, niespełnionych pragnień, z niewiedzy i wiary... a teraz spojrzę na niego... wyrozumiale. A to uśmierca bogów (s. 83).

Bohater uświadamia sobie, że jedynym wyjściem z sytuacji pozostaje przestrzeń myśli „,wolnej i wątpiącej”. Kompozycja sceniczna, jaką posługuje się tutaj Pankowski działa wielopoziomowo. W pierwszej części utworu odbiorca przyjmuje punkt widzenia książąt. Poznaje rzeczywistość sceniczną z perspektywy wielkiej narracji biblijnych oczekiwań, skonfrontowanej co prawda z ironicznymi uwagami wygłaszanymi chociażby przez braci Józefa, która nie traci natomiast w wyniku tego zestawienia swojej mocy „obrazotwórczej”. Czytelnik za pomocą tej struktury słownej wchodzi w świat, którego fundamenty zbudowane zostają na elementach wielkiej narracji biblijnej. Pozbawiony jednak zostaje szans na obserwację samego obrazu. Autor Biwaku odzierając utwór z kluczowej sceny oddania Dzieciątku pokłonu przez Kaspra, Melchiora i Baltazara, doprowadza w analizowanym fragmencie do sytuacji, która przypomina „podglądanie” rzeczywistości przez „dziurkę od klucza". Wypowiedzi bohaterów opisują scenę w szopce w taki sposób, że odbiorca ma wrażenie, jakby razem z nimi obserwował doświadczany przez nich obraz (co ważne percepcja ta odbywa się z czytelnie zasygnalizowanym przesunięciem czasowym), mimo iż do niego samego nie ma jednak dostępu. Komentarze dramatis personae dotyczące ich własnych oczekiwań wytrącają odbiorcę z procesu obserwacji. Zastosowana przez Pankowskiego strategia komunikacyjna przypomina tym samym strukturę anamorfozy. Pankowski, dzięki szczególnemu połączeniu narracji o obrazie z uwagami poświęconymi uwarunkowaniom percepcji, otwiera przestrzeń, w której oglądać można własne widzenie. W tym kontekście wypowiedź Kaspra uzyskuje niepowtarzalne znaczenie:

\section{KASPER}

Mędrcyśmy, a żal nam drogi darmo przebytej, jak ludziom u schyłku życia żal lat przeżytych... Jak inni lękamy się robactwa czy popiołu, co po nas pozostanie.... i dlatego wierzymy, dlatego twierdzimy.... że tak długiej drogi nie można przebyć bez sensu... że wszystko jest po coś. I chcemy nadal iść, nadal wierzyć... aby nadal móc drżeć na myśl o myśli, której daliśmy na imię „Bóg” (s. 76).

Przywołany passus traktować należy jako wyraz szczególnej samoobserwacji dokonywanej przez postać sceniczną, słowa zamkniętego w innym słowie, „widzenia samego siebie w dramatycznym świetle”. W tym właśnie momencie otwiera się przestrzeń zerowego punktu widzenia. Aktu autopercepcji, który łączy nadawcę i odbiorcę. Słowa Kaspra są wyjątkowe w swojej wymowie właśnie dlatego, że łączą perspektywę nadawcy, bohatera i odbiorcy tekstu. Narracja 
dramatyczna jest zaś właśnie tą, która rodzi się w scenicznym punkcie zero. W momencie, kiedy dramat staje się opowieścią o widzeniu, co trzeba jednak zaznaczyć, niepowtarzalnym. Nieograniczonym bowiem ani do metateatralnych uwag przypisywanych podmiotowi dramatycznemu, monologowych autorefleksji bohatera czy miejsc bezpośrednich zwrotów ad spectatorem. W dramacie, jako chyba jednym gatunku literackim, możliwe okazuje się wytworzenie szczególnego pola percepcji stanowiącego wynik przecięcia się linii perspektywy odbiorcy, nadawcy i postaci scenicznej.

Jeśli przyjąć, zgodnie zresztą z większością badań poświęconych dramatowi religijnemu, że wyższy, duchowy sposób rozumienia rzeczywistości prezentują w dramacie bohaterowie opowiadający biblijną historię świata, to analizowane w tym artykule sceny można traktować jako wyraz ograniczeń, które na mistyczny obraz nakładają „materialne” warunki widzenia. Trudno nie zauważyć, że „towarzyszące” narracjom dialogi są czytelnie osadzone w mikrokosmosie dramatycznym. Stają się więc one sygnałem istnienia przesłony, która determinuje sposób percepcji obrazów prezentowanych w monologach protagonistów. To jednak właśnie one - skonfrontowane z wielkim obrazem biblijnym (lub jego brakiem jak u Pankowskiego) otwierają drogę do wejścia w załamanie, przepaść tych opowieści, a poprzez nie - do prawdziwego doświadczenia Słowa.

Dzieła omawianych tutaj autorów dzieli ogromny dystans czasowy, różnica doświadczeń historycznych, społecznych, wizja literatury i roli słowa poetyckiego. Warto jednak zauważyć, że problematyka, którą ujawniają przeprowadzone analizy, zmienia sposób postrzegania nie tylko widowiskowości Betlejem polskiego i Biwaku pod gotym niebem, lecz także samego gatunku jasełek uznawanego dotychczas za dość schematyczną i konwencjonalną, acz ludową opowieść o Narodzeniu Pańskim. Wskazane tutaj zjawiska mogą się więc okazać przydatne do analizy swoistych modyfikacji tego wzorca, jakich upatrywać można w Królewnie Orlicy. Misterium-jasetkach, Nocy rabinowej Tadeusza Micińskiego, czy chociażby Jasetkach moderne Ireneusza Iredyńskiego.

\section{Bibliografia}

M. Bokczyszanin, Kolęda, w: Stownik literatury staropolskiej, red. T. Michałowska, Wrocław 1998.

B. Dąb-Kalinowska, Ikony i obrazy, Warszawa 2000.

J. Dürr-Durski, Jak powstała polska szopka betlejemska?, w: Literatura, komparatystyka, folklor. Księga poświęcona Julianowi Krzyżanowskiemu, pod red. M. Bokszczanin, S. Frybesa, E. Jankowskiego, Warszawa 1968.

P. Evdokimov, Sztuka ikony. Teologia piękna, przeł. M. Żurowska, Warszawa 1999. 
P. Florenski, Ikonostas i inne szkice, przeł. Z. Podgórzec, Warszawa 1981.

I. Górska, Dramat jako filozofia dramatu na przykładzie twórczości Tadeusza Różewicza, Poznań 2004.

I. Jazykowa, Świat ikony, przeł. H. Paprocki, Warszawa 1998.

R. Kapłanowa [M.R. Mayenowa], „,Wesele” Stanisława Wyspiańskiego. Problemy kompozycji, Warszawa 2013

K. Klauz, Teologiczna hermeneutyka ikony, Lublin 2000.

T. Kowzan, Teatr w teatrze czyli o dialektyce iluzji scenicznej, „Dialog” 1971, nr 4.

T. Kowzan, Znak i teatr, Warszawa 1998.

K. Kurek, W. Wydra, Miedzy „, sacrum “ a ,profanum “... Nieznany tekst pastorałki dramatycznej z kregu kaliskiego kolegium jezuickiego, w: Ko-mediana. Prace ofiarowane Profesor Dobrochnie Ratajczakowej, pod red. E. Guderian-Czaplińskiej i K. Kurka, Poznań 2013.

K. Latawiec, Scena ,bożych kukiet”, w: tejże, Na scenie świata i teatru. O dramaturgii Mariana Pankowskiego, Kraków 1994.

S. Mullaney, Miejsce sceny. Zezwolenie, teatr $i$ władza $w$ renesansowej Anglii, przeł. O. Kaczmarek, w: Teatr elżbietański, red. A. Chałupinik, Warszawa 2015.

J. Skuczyński, "Moc przeze mnie gada" Autor i jego strategie nadawczo-odbiorcze, w: Świat z tajemnic wyspowiadany... Studia o „, Samuelu Zborowskim” Juliusza Stowackiego, pod red. M. Kalinowskiej, J. Skuczyńskiego i M. Bizior, Torun 2006.

J. Słowacki, Glosy na marginesie egzemplarza „Biblii”, w: tegoż, Dzieła, red. J. Krzyżanowski, t. 11, Warszawa 1959.

D. Ratajczakowa, Stuga dwóch panów: dwoisty żywot dramatu, „Teksty Drugie" 1990, nr 5-6.

K. Ruta-Rutkowska, $O$ dwóch dramatach Mariana Pankowskiego, „Ogród” 1992 nr 3-4.

A. Ubersfeld, Lire le théătre III. Le dialogue de théătre, Paris 1966.

B. Uspieński, O systemie przekazu obrazu w rosyjskim malarstwie ikon, w: Semiotyka kultury, wybór i oprac. E. Janus i M. R. Mayenowa, Warszawa 1977.

B. Uspieński, The Semiotics of the Russian Icon, Lisse 1976.

M. Quernot, Ikona. Okno ku wieczności, przeł. H. Paprocki, Białystok 1997.

R. Weimann, Shakespeare i tradycja ludowa, przeł. P. Morawski, w: Teatr elżbietański, red. A. Chałupinik, Warszawa 2015. 


\section{Streszczenie \\ Dramatyczna narracja - między Betlejem polskim Lucjana Rydla a Biwakiem pod golym niebem Mariana Pankowskiego}

Autorka artykułu analizuje szczególną strukturę formy dramatycznej związanej z motywem wędrówki do Betlejem czyli jasełek. Wykorzystując rozpoznania Marii Renaty Mayenowej, dotyczące potencjału semantycznego tej formy, analizuje konkretne realizacje tej formy. Porównanie utworów Lucjana Rydla oraz Mariana Pankowskiego skupia się przede wszystkim na rozważaniach dotyczących unikalnej formy narracyjnej tekstu dramatycznego, ściśle związanej z opowieścią biblijną. Możliwości nowoczesnego ujęcia tego problemu autorka upatruje w analizie momentów przecięcia się punktów widzenia poszczególnych postaci obydwu dramatów z organizowaną przez podmiot dramatyczny czasoprzestrzenią utworów. Uzyskane w ten sposób pole komunikacyjne odpowiada pozycji zajmowanej przez podmiot dramatyczny. Precyzyjne jej wyznaczenie daje szansę na odtworzenie schematów komunikacyjnych obydwu dzieł i dostrzeżenie charakterystycznych dla twórczości dramatycznej przekształceń narracji biblijnej.

\section{Summary \\ Dramatic narration - between Polish Bethlehem of Lucjan Rydel and Camping Rough of Marian Pankowski}

The author of the article analyses the particular structure of dramatic form related to the motif of journey to Bethlehem, that is Nativity Play. Using the Maria Renata Mayenowa's reflections on the semantic potential of this form, the author analyses its specific productions. The comparison between works by Lucjan Rydel and Marian Pankowski focuses mainly on reflections considering the unique narratic form of a dramatic text, tightly related to the biblical gospel. The authors sees possibilities to grasp this problem in a modern fashion by analyzing the moments in which the viewpoints of particular characters from both works cross with the space-time organized by the dramatic subject. The field for communications, hence obtained, reflects the position occupied by the dramatic subject. By defining it accurately, we are given a chance to recreate the communications schemes of both works and to notice the transformations of biblical narration characteristic of dramatic art. 